Sci., 230, 633 ('55); 247) V. Altmann, M. Nelson, D. Pernova: Am. J. Clin. Path., 26, 956 ('56); 248) R. E Stoner, H. F. Weisberg: Clin. Chem., 3, 22 ('57); 249) 伊藤経亮: 䀲休病理, 5, 249 ('57); 250) 水田信夫, 名和田智, 赤 間宏: ibid., 3, 250 ('55)

251) 石井好明, 赤沢章嘉, 垉越弥太郎: 臨床病理, 5, 167 ('57); 252) H. C. Elliot: Anal. Chem., 29, 1712 ('57); 253) R. D. Lewis, A. G. Foord: Am. J. Clin. Path., 25, 199 ('55); 254) P. B. Donovan, W. J. Tighe: J. Lab. \& Clin. Med.,
46, 895 ('55); 255) H. L. Segal, L. L. Miller, E. J. Plumb: Gastroenterology, 28, 402 ('55); 256) J. T. Galambos, J. B. Kirsner: Arch. Int. Med., 96, 752 ('55); 257) J. K. Kirby, C. F. Pelphrey J. R. Rainey: Am. J. Clin. Path. 27, 360 ('57); 258) H. A. Frank, M. H. Carr: J. Lab. \& Clin. Med., 45, 973, 977 ('55); 259) B. Abrams, T. C. Everson, T. Fields, E. Kaplan: ibid., 49, 494 ('57); 260) W. J. Small, M. C. Verloop: ibid., 47, 255 ('56).

\title{
23 裁判化学
}

\section{奥 井 誠 一.石 倉 俊 治*}

裁判化学の分野で最も多く行われる試験としては，

(1) 死因なたは中毒の原因となった毒物の生体から の検查

（2）医薬品，膚瑟物特に麻薬，党醒剂の鑑定

（3）血液中のアルコール，一酸化炭素(焼死の場合) などが多く，ついで放火事件の揮発油等の鑑定，犯行現 場の遺留品について, 血㾯試験, 色幸顔料などの附着物

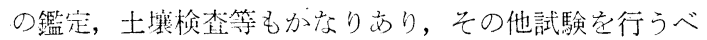
き対象となるものはその種類がきわかて多く，範囲を限 定すること㳊型難であるが，ここでは中毒の原因として 最も踑度の高い劇恝物のいくつかについての鑑定定量方 法についての最近の進歩を岩りかえつてみることにす る・またすでに編集された，薬事分析その他の項と若干 重複一ることもあるが, 榆体の取扱方法や試験の目的に 注自ら差があるのでは2, ここではこれらを含めて記すこ とに可る。

\section{$23 \cdot 1$ 青酸}

青酸は現在でも裁判化学上最も多く遭遇する毒物の一 つである・督酸の生体物質からの定量法としては，血清， 血漿中の青酸をブロムシアンとなし，ベンチヂンーピリ シンにて発色させ比色する方法3)，血液中のシアンへモ グロビンを分光光電比色法にて定量する方法4), 李た微 量昖政装置老用いる方法としては，水酸化カリウム液に 吸收させた青酸芯アンモニア水，およびヨウ化カリウム

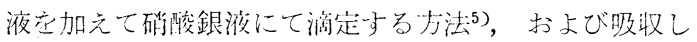
た青酸を chloramine $\mathrm{T}$ 液，1-pheny1-3-methy1-5pyrazolone 飽和溶液, 4, 4'-bis (1-pheny 1-3-methy15-pyrazolone）のピリヂン 溶液にて 発色させ $630 \mathrm{~m} \mu$ の吸收を測定する方法6なよ゙がある。

* 東京大学薬学部衛生裁判化学教室（東京都文京区本富士町）
定性試験には以前から行わ礼たロダン反応，ベルリン 青反応などが現在も用いられているがその他benzoin 縮 合による方法7)，およびベンチジン法を改良し携且，保 存に便とならしめる改良法が報告されているす.

\section{$23 \cdot 2$ アルコール}

裁判化学上，エチルアルコールの検出，定量は毒物と してでなく，飲酒時の犯罪や交通事故9)の際の酩酊状態

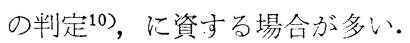

定量法として, アルコールをクロム酸硫酸に吸収, 酸 化させた後，チ才硫酸ソーダ液にて滴定するウイドマ一 ク法がよく行われるが，ク口ム酸硫酸を $460 \mathrm{~m} \mu$ の比色 艺行う改良法11およびアルコール脱水素酵素による定量 法 ${ }^{12)}$ ，ウイドマーク法と酵素法との比較検討した報告13) もある・

また血中のアルコールの濃度が死後に減少する速度 について ${ }^{14)}$ ，および死後の腐败過程においてバクテリ アによりアルコールの生成されることも報告されてい る15)16).

また呼気中アルコールの検知管による簡易定量法もあ $3^{17)}$.

血中心よる生体物質中のメタノールを $\mathrm{KMnO}_{4}$ 酸化 後，2,7-naphtalendiol にて赤紫色に発色させる定性試 験 ${ }^{8)}$, メタノール, エタノールを 3,5-dinitrobenzoylchloride にて不揮発性の誘導体となし，20\% dioxan にて展開し， $\alpha$-naphthylamine にて発色せし的て，分 離確認寸る方法がある ${ }^{19}$.

\section{$23 \cdot 3$ 催 眠 剂}

催跟刜は裁判化学上しばしば問題となるものでいわゆ る流行毒となったものが多い. 特にバルビツール酸誘導 


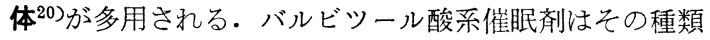
も多いので分離, 検出にペーパークロマドグラフ法21は しばしば用いられる. その展開溶媒には，アンモニア性 ブタノール22) 24), アンモニア性アミノアルコール25)な どがよく用いられるほか, 各種アルコールのアルカリと の混液を用いる方法 ${ }^{26)}$, 口紙を $\mathrm{pH} 10.5$ のホウ砂緩衝 液にて処理し，クロロホルムにて展開する方法27，口紙 上電気泳動法によるもの ${ }^{28)}$, アセトンー水の等容混液に ジメチルアミンを飽和させた溶媒, ジメチルアミン飽和 水をブタノールに飽和させたもの，イソプロピルアルコ 一ル, クロロホルム, アンモニア水の混合溶媒を用いる など多種の方法が発表されている.

発色剂としては，不飽和を有するものに対しては

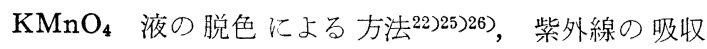
によるものも報告されている27). 又との他 $0.1 N$ 硝酸

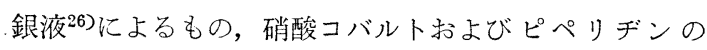
蒸気によるもの ${ }^{25}$, 塭化コバルトーアンモニア23) による もの, スポットを抽出し，アルカリ液捻よび緩衝液中で の吸収を測定し，定性および定量を行なう方法がある.

定性試験法としては，1\%おおび 10\% 酢酸銅ーアンモ ニア液を加え生ずる結晶の色（紫, 青, 無色または黄色） により分類する方法 ${ }^{29)}$, 水またはアンモア二水から再結 乙結晶形, 溶融, 昇萃を顕微鏡にて観察し, X 線回折を 行なう方法 ${ }^{30} 311$, 硫酸銅-ピリジン液との反応物の融点 を測定する方法 ${ }^{32)}$, 新しい呈色反応によるもの ${ }^{33) な と ゙ か ゙ ~}$ あり,また光電比色定量法としては, 直接アルカリ液中 および緩衡液中の紫外部の吸収を測定し，その差より定

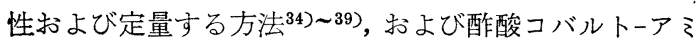
ルアルコールにより発色させ比色する方法が報告されて いる40).

また，スタス・オット法，酵素消化法，イオン交換樹 脂法などによる臓器中のバルビッレートの抽出法を比較 検討した報告もある ${ }^{41)}$. 最近新しくできた非バルビッー ル系の催眠剂では, methylpylon の性質, 化学反応, 定量法 ${ }^{42)}$, glutethimide $の$ hydroxamic acid $と \mathrm{Fe}^{3+}$ による検出法 ${ }^{43)}$, ethynamate の性状, およびペーパ 一クロマトによる検出44および結晶形，X線回析につい て45)などの報告がある.

また古くから用いられた bromisovalerylurea，およ び bromdiethylacetylurea のペーパークロマトグラ フ法としては，アンモニア性ブタノールにて 展開し， $\mathrm{KOH}-\mathrm{AgNO}_{3}$ にて発色させる方法 ${ }^{46)}$ ，および $5 \%$ アン モニアと加熱して生じた分解物を同様な溶媒系で展開 し, bromcresolpurple にて発色せしめて分離検出する 方法がある47).

\section{3 • アルカロイド执よび塩基性薬品}

アルカロイド類の生体からの分離, 検出には広くペー パークロマト法が用いられる56).

その主なものをあげるとブタノール：氷酢：水の溶媒 系でモルヒネを48)，アコニット根アルカロイドを49), 麻 薬類を(50)51)，メサドン，エフェドリンその他を52)，展開 する方法, また各 $\mathrm{pH}$ の緩衡液で処理した口紙で展開す る方法 ${ }^{53}$ 54), 電気泳動を利用する方法などがある55).

また分光光電比色法による分析も数多く行われてい る.すなわち, コカイン 57588), ヘロインおよびキニー ネ59), コカイン, プロカイン, テトラカイン60)の検出,

各種アルカロイド61), ナルセイン ${ }^{62)}$, アヘンアルカロ イド類 ${ }^{63) ~ 67), ~ ア ホ ゙ モ ル ヒ ネ ゙ 6), ~ チ ゙ チ エ ニ ー ル ア ミ ノ フ ゙ ~}$ テン系麻薬68)，4,4-dipheny1-6-dimethylamino-3hexanon (合成麻薬) ${ }^{69)} な と ゙ の$ 紫外部に於ける吸収の研 究が発表されている.

また酸性指示薬と結合させ有機溶媒に転溶させ比色定 量する方法70)(1), その他モルヒネのヨード酸-炭酸アン モンーニッケル塩反応に基ずく特異な定量法72), アルカロ イドと bismuthethylenediamine-tetra- acetate-ヨ 一ドカリと反応させ遊離した ethylendiamine tetra acetic acid を硫酸西鉛液で滴定する定量法 ${ }^{73)}$, 尿中のモ ルヒンのポーラログラフによる定量 ${ }^{74)}$ ，アコニットの生 物学的定量法 ${ }^{75)}$, 組織中モルヒンを Folin 試薬により発 色し, 比色定量する方法 ${ }^{76)}$, アルカロイドの potassium tetraphenylboron による沈殿反応 ${ }^{77)}$, ニコチンの特異 鋭敏反応 $^{78)}$, アヘンアルカロイドの複呈色反応 ${ }^{79)}$, ア之 ノブテン 系麻薬の 検出法80) 85), 4,4-diphenyl-6-dimethyl-3-hexanon (合成麻薬) の検出69)，などが報告 されている.

\section{5 重 金 “属}

23.5.1 水 銀 定量法はジチゾンによる比色が鋭: 敏であり広く用いられるが，水銀は有機物壤機中に揮散 しやすいので, 壤機法について色々と報告されている. 組織を硝酸処理後, 過マンガン酸カリで酸化する方法 ${ }^{86)}$, 尿を過酸化水素にて酸化する方法 ${ }^{87)}$ ，尿を耐圧ビン中で 硝酸, 過マンガン酸カリで酸化する方法 ${ }^{88)}$, 尿を第一塩 化錫で還元し，蒸留して分離して後ジチゾンで比色する 方法など89)が報告されている。

その他 thiobenzamide による定量法90).

尿中の SH group の水銀分析の阻害とその除去法 ${ }^{91}$ ? などがある。

23.5.2 ヒ 素生体物質中の定量法として兏化後 
還元し，溶液に集め heteropoly blue として比色する 方法92がある.

23.5.3 鉛 血液中その他の鉛を酸化後, 混色ジチ

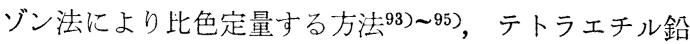
の肝臓よりの分離，検出 ${ }^{96)}$. 鉛中毒時 ${ }^{97)}$ ，および四エチ ル鉛中毒時の鉛の生体内分布 ${ }^{98)}$ ，に関する報告がある.

\section{交 献}

1）塚元久雄，奥井誠一: “裁判化学” (58)；2）血井誠一：分 化, 5, 189 ('56); 3) R. B. Bruce: Anal. Chem, 27, 1346 ('55); 4) N. J. Duchateau: Am. J. Med. Technol., 23, 17 ('57); 5) 竹村豊造: 科捜, 8, 68('55); 6) M. Feldstein, N. C. Klendshoy: J. Lad. Clin. Med., 44, 166 ('54); 7) F. Feigl, A. Caldas: Mikrochim. Acta., 1955, 992 ('55); 8）堤正雄, 角谷昭三，福田公郎：科搜，10，61 ('57)；9） G. N. Lueas: C. A., 48, 3571 ('54); 10) J. J. Prag, S. Abrican: J. Med, Sci., 18, 141 ('53)

11) O. Grüner: Naturwissens chaftten, 40, 365 ('53); 12）見出健次：法医，11，737 ('57); 13) R. Bonnichsen, Gösta Lundtren: Acta. Pharm. Toxicol., 13, 256 ('57); 14）草刚一友: 医学と生物学, 23, 95 ('52); 15) R. K. Bomrichsen, K. O. Moller, H. Theoridl: Acta. Pharmacol. Toxicol., 9, 352 ('53); 16) H. Gormsen; J. Forensic Scl., 1, 314 ('54); 17) 西山誠二郎,本橋信夫: 科捜, 9, 21('56); 18) O. E. Skaug; Scand. J. Clin. Lab. Invest., 8, 338 ('56); 19) 松元弘已: 科拽, 10, $37\left({ }^{\prime} 57\right)$; 20) 山村酹一; 利捜, 7, 59 ('54)

21) E. Lederer, M. Lederer: Chromatography, 367('57); 22) A. S. Curry; Acta Pharm. Tox. Kbh-, 13, 357 ('57); 23）高原, 谷口, : 蒋剤部長会年報, 13, 119 ('55); 24) C. Reibeling, H. Burmeister: Klin Wachochr. 32, 1057 ('54); 25) G. Hübner, E. Pfeil: Hoppe-Seylers. Z., 296, 225 ('54); 26) L. G. All'gen: scand. J. Clin. lab, Invest, 9, 71 ('57); 27) J. T. Wright: J. Clin. Pathol., 7, 61 ('54); 28）木下弥兵衛，森山繁降：薬誌，75, 796 ('55); 29) H. M. Romijn: Pharm. Weekbl, 92, 397 ('57); 30) W. G. Penprase, J. A. Billes: J. A. PA, 45, 585 ('56)

31）山村酹一, 丹羽口: 科拽, 10, 13 ('57); 32) L. Levi, C. E. Hubley: Anal Chem. 28, 1591 ('56); 33) B. Danielsson; Svensk Farm. Tidsky, 58, 511 ('54); 34) J. Brauman: Acta clin. belg., 9, 262 ('54); 35) R. Askevolk, F. Loken: Scand. J. Clin, Lab. Invest., 8, 1 ('56); 36) J. W. Huisman: Pharm. Weekbl., 91, $505\left({ }^{\prime} 56\right)$; 37) P. M. G. Broughton: Biochem. J., 63, 207 ('56); 38) A. S. Curry: J. Pharm. Pharmacol, 9, 102 ('57); 39) S. Goldschmidt. W. Samprecht, E. Helmreich: Hoppe-Segler's Z. 292, 129 ('53); 40) V. P. Argiles, J. M. B. Beguiristain: Arch. med-expt1, 16, 145 ('53)

41）川原俊夫：法医，9，116（'55)；42）青木勇治, 木村武司， 横山修一, 科捜, 10, 43 ('57); 43) H. Sheppard, B. S. D'asaro, Albert: J. A. P A., 45, 681 ('56); 44) 木村武司: 科搜, 11, 10 ('58); 45) A. V. Camp. R R. Pfeiffer: I. A.
P. A., 48, 571 ('57); 46) 片山義顕, 菊地章: 薬剤部長会年報, 14, 41 ('54); 47) 脇田耀, 高原, 谷口: ibid., 13, 121 ('55); 48）米田, 西本, 高野, 滝川: 科搜 $11,7\left({ }^{\prime} 58\right)$; 49) 土谷保: 法 医, 鑑識, 社会医学, 1, 218 ('54) 2, 73, 96 ('56); 50) M. S. Pobro, S. Kusafuka; J. Criminal daw. Crim. Pol. Sci., 44, 247 ('53)

51) G. J. Mannering, A. C. Dixon, N. V. Carroll, J. Lab. Clin. Med., 44, 292 ('54); 52) F. Aboffy, S. Kveder: Acta Pharm. Jug., 6, 209 ('56); 53) L. R. Goldbaum, L. Kazyak: Analy. Chem., 28, 1289('56); 54) A. Bettschart, H. Flück: Pharm. Act Helvet., 31, 260 ('56); 55) E. Garf, D. P. H. List: Arznei-mittel-Forsch., 4, 450 ('54); 56) E. Laderer, M. Lederer: Chromatsgraphy, 209 ('57); 57）柳原炤観：法医, 11，750 ('57); 58） F. M. Ampuero, M. J. Echea; C. A., 47, 95600 ('53); 59) M. J. Pro, W. P. Butler, A. P. Mathers: J. A. O. A. C., 38, 849 ('55); 60) M. J. Pro. R. A. Nelson, ibid., 39, 975 ('56)

61）収角三郎：法医， 9， 532 ('55); 62） A. H. Wette: Pharm. Weeḳbl., 91, 588 ('56); 63) M. S. Dger, A. J. Mchay: J. A. P. A., Sci. Ed., 44, 156 ('55); 64) M. Sdywe, A. J. McBay: ibid., 44, 156 ('55); 65) 岡田和中: 科搜，11，14 ('58); 66) 真鋗貞光：法医, 10, $341\left({ }^{\prime} 56\right)$; 67) 松浦朔郎: ib!d., 12, 43 ('58); 68) 成立弘: 科捜, 8, 36 ('55); 69) 吉田炤一郎: ibid., 9, 89 ('56); 70) Z. I. El Darawy, S. L. Tompsett. Analyst, 81, 601 ('56)

71）秋谷七郎，本橋信夫; 法医, 10, 478 ('56); 72) R. R. A. Pride, E. S. Stern, J. Pharm. Pharmacol., 6, 596('54); 73) B. Budesinsky: J. Pharm. Pharmacol., 9, 485 ('57): 74) P. Paerregaard: Acta Pharm. tox. Kbh., 14, 38 ('57); 75) A. Crema. Farmaco, Ed. sci., 12, 639 ('57); 76) F. Moya, J. C. Szerb. D. P. MacLeod: Arch. int. Pharmacodyn. 109, 99('57); 77) L. Rosentaler; F. Lüdy-Tenger: Pharm. Acta Helvet., 32, 35 ('57); 78) P. Luis: Anal. Abst. 1, 2506 ('54); 79) S. S. Cheng: J. A. P. A. Sci. Ed. 43, 767 ('54); 80) 秋谷七郎, 中沢泰男, 石倉俊治: 薬誌, 77, 931 ('57)

81）稻野穎式：法医，9，1 ('55)；82）生田分平，森川千春, 科 指, 8, 76 ('55)； 83) 成行弘: ibid., 36 ('55); 84) 岩崎斉: ibid., 49 ('55); 85) 神田瑞穂, 三村公正: ibid., 10, 270('57); 86) F. R. Barrett: Analyst, 81, 294 ('56); 87) V. L. Miller, F. Swanbarg. Jr.: Anal. Chem., 29, 391 ('57); 88) A. C. Roffo. F. R. Russell. N. T. Wilkinson: Analyst, 80, 523 ('55); 89) M. Houskova: Pracovni. Likarstvi, 5, 339 ('53); 90) E. Gagliardi, W. Haas: Mikro Chim. Acta., 599, 603 ('54)

91) I. M. Weiner, O. H. Müller: Anal. Chem., 27, 149 ('55); 92) R. J. Evans, S. L. Bandemer: ibid., 26, 595 ('54); 93) P. E. Cornish. D. O. Shiels: Brit. J. Ind. Med., 11, 156 ('54); 94) S. L. Tompssett: Analyst, 21, 330 ('56); 95) D. Abson, A. G. Lipoconh: ibid., 82, 152 ('57); 96) C. D. Stevens, C. L. Feldhake. R. A. Kehoe. J. Pharmacol., 117, 420 ('57); 97) K. H. Stroka: Arch. Metalkunde, 3, 429 ('52); 98) A. Morelli. P. Preziosi. C. A. 48,8972 ('54). 